\title{
Analisis Persepsi Wajib Pajak Pelaku UMKM Terhadap Penerapan Peraturan Pemerintah Nomor 23 Tahun 2018
}

\author{
Teguh Setiawan* \\ Fakultas Ekonomika dan Bisnis, Universitas Kristen Satya Wacana
}

\section{A R T I C L E I N F O}

Article history:

Received 19 August 2019

Received in revised form

16 September 2019

Accepted 15 October 2019

Available online 30

November 2019

\section{Kata Kunci:}

Wajib Pajak UMKM

Peraturan Pemerintah

Nomor 23 Tahun 2018

Keywords:

Taxpayers SMEC,

Government Regulation

number 23 year 2018

\begin{abstract}
A B S T R A K
Penelitian ini bertujuan untuk menganalisis dan memberikan gambaran mengenai persepsi wajib pajak pelaku UMKM terhadap Peraturan Pemerintah Nomor 23 Tahun 2018 ditinjau dari tarif pajak, sanksi pajak, kemudahan pajak dan sosialisasi. Jenis penelitian ini yaitu deskriptif yang mendeskripsikan persepsi wajib pajak terhadap Peraturan Pemerintah Nomor 23 Tahun 2018. Sampel dari penelitian ini sebanyak 100 responden dengan teknik convinience sampling. Teknik analisis data menggunakan uji validitas, uji reliabilitas dan analisis data deskriptif. Hasil penelitian menyebutkan bahwa persepsi Wajib Pajak Pelaku UMKM terhadap Peraturan Pemerintah Nomor 23 Tahun 2018 di tinjau dari tarif, sanksi, kemudahan dan sosialisasi pajak secara keseluruhan sudah cukup baik, serta telah memberikan pemahaman dan menawarkan kemudahan dalam pembayaran pajak pelaku UMKM.
\end{abstract}

\section{A B S T R A C T}

This research aims to analyze and give you an idea about the perception of the perpetrator of the SMEC taxpayers against government regulation Number 23 year 2018 in terms of tax rates, tax, tax ease sanctions and socialization. This kind of descriptive research that describes the perception of taxpayers against the Government Regulation Number 23 year 2018. The sample of this research as much as 100 respondents with the technique of sampling convinience. Data analysis techniques using the test validity, reliability test and descriptive data analysis. Results of the study mentioned that the perception of the perpetrator of the SMEC Taxpayers against government regulation Number 23 year 2018 in the review of tariffs, ease sanctions, and socialization in overall taxes are already quite good, and has given the understanding and offers convenience in payment of tax the perpetrators of SMEC.

\footnotetext{
* Corresponding author.

E-mail addresses: teguhsetiawan@gmail.com (Teguh Setiawan)
} 


\section{Pendahuluan}

Pada tanggal 22-23 Juni tahun 2018 di Bali dan Surabaya, Presiden Joko Widodo menerbitkan aturan mengenai penurunan tarif pajak Usaha Mikro, Kecil, dan Menengah (UMKM) menjadi 0,5 persen. Hal ini diterapkan untuk mengoptimalkan penerimaan pajak dari sektor UMKM. Aturan tersebut diatur dalam Peraturan Pemerintah Nomor 23 Tahun 2018 tentang Pajak Penghasilan atas Penghasilan Usaha yang Diterima Wajib Pajak yang Memiliki Peredaran Bruto Tertentu. Peraturan ini menggantikan peraturan sebelumnya, yaitu PP Nomor 46 Tahun 2013 dengan tarif PPh final UMKM sebesar 1 persen yang ditujukan bagi UMKM yang beromzet kurang dari Rp 4,8 miliar dalam setahun (Sari, 2018).

Perubahan tarif ini dilakukan karena adanya desakan dari pelaku usaha khususnya UMKM yang merasa bahwa tarif PPh Final atas penghasilan bruto tertentu yang berlaku selama ini terlalu besar dan memberatkan para pelaku usaha. Terkait hal ini, wajib pajak pada akhir tahun 2018 diharapkan dapat tumbuh lebih dari 1,96 juta pelaku dengan adanya kebijakan insentif pajak yang diterapkan pemerintah. Namun dilihat dari skala usaha UMKM, potensi wajib pajak baru yang dapat menjadi fokus utama dari kebijakan ini adalah kelompok pelaku usaha kecil sejumlah $681.522(1,15 \%)$ dan pelaku usaha menengah mencapai 60 ribu $(0,1 \%)$. Dilihat dari persentase kedua kelompok usaha tersebut dapat disimpulkan bahwa kelompok pelaku usaha kecil lebih siap menyetor pajak dibandingkan dengan pelaku usaha mikro (Setiawan, 2018).

Penelitian Suhendri (2015) menjelaskan bahwa salah satu faktor yang mempengaruhi rendahnya kepatuhan wajib pajak orang pribadi dalam membayarkan kewajibannya adalah tarif pajak. Pembebanan pajak yang rendah membuat masyarakat tidak terlalu keberatan untuk memenuhi kewajibannya. Sehingga dapat dipahami bahwa semakin adil tarif pajak yang ditetapkan maka semakin tinggi tingkat kepatuhan wajib pajak dalam membayarkan kewajibannya. Dalam hal ini PP Nomor 23 Tahun 2018 diharapkan dapat menumbuhkan jumlah wajib pajak pelaku UMKM, karena tarif pajak yang ditawarkan lebih rendah dari pada tarif pajak sebelumnya.

Selain itu penerapan PP Nomor 23 Tahun 2018 dimaksudkan untuk memberikan kemudahan bagi wajib pajak UMKM dalam bentuk tarif yang rendah, cara perhitungan sederhana, serta mekanisme pelunasan dan pelaporan yang mudah. Menurut BG Consulting (2003), kemudahan pajak dapat dicapai melalui kemudahan dalam sistem pajak, undang-undang pajak, dan penetapan aturan-aturan perpajakan. Artinya, wajib pajak tidak mengalami kesulitan dalam menghitung dan menyetor jumlah pajak terhutang sesuai dengan ketentuan perundang-undangan. Selain itu, Hotlzman (2007) menyebutkan bahwa sistem pajak yang mudah akan mengurangi beban kepatuhan pajak dibandingkan dengan sistem pajak yang kompleks.

Penerapan peraturan baru tersebut memerlukan sosialisasi yang memadai. Andriani dan Herianti (2015) mengungkapkan bahwa dengan meningkatkan sosialisasi ke seluruh lapisan masyarakat diharapkan dapat mempengaruhi wajib pajak dalam melakukan kewajiban membayar pajak. Bukan hanya itu, adanya sosialisasi perpajakan dapat memberikan gambaran penting mengenai pajak dari banyak sisi termasuk mengenai bagaimana membayar dan melaporkan kewajiban perpajakannya.

Penelitian Norsain dan Yasid (2014) menunjukkan bahwa perubahan tarif, kemudahan membayar pajak dan sosialisasi PP Nomor 46 Tahun 2013 berpengaruh signifikan terhadap persepsi wajib pajak pelaku UMKM. Artinya semakin baik persepsi wajib pajak atas pemberlakuan PP Nomor 46 Tahun 2013, maka wajib pajak UMKM akan semakin patuh dalam memenuhi kewajiban perpajakannya. Di Kota Salatiga potensi pajak UMKM belum begitu besar sedangkan pertumbuhan UMKM dari tahun ke tahun semakin bertambah, karena itu penurunan pajak PPh final menjadi 0,5 persen ini, diharapkan dapat menumbuhkan kesadaran masyarakat dalam membayar kewajiban pajaknya.

Di samping itu, sebelum diberlakukannya penurunan tarif pajak kesadaran akan pembayaran pajak pada UMKM masih rendah sehingga diberlakukan sanksi pajak. Menurut Masruroh (2013), sanksi pajak merupakan hukuman terhadap keterlambatan maupun kekurangan atas kewajiban pajak yang ditanggung oleh wajib pajak. Penerapan sanksi tersebut bertujuan untuk meningkatkan kepatuhan pajak dan diharapkan dapat menurunkan jumlah sanksi maupun pelanggaran mengenai sanksi perpajakan.

Berdasarkan penjelasan di atas maka penelitian ini akan menguji bagaimana persepsi wajib pajak pelaku UMKM terhadap PP Nomor 23 Tahun 2018 ditinjau dari tarif pajak, sanksi pajak, kemudahan pajak dan sosialisasi? Adapun tujuan penelitian ini ialah untuk menganalisis dan memberikan gambaran mengenai persepsi wajib pajak pelaku UMKM terhadap PP Nomor 23 Tahun 2018 ditinjau dari tarif pajak, sanksi pajak, kemudahan pajak dan sosialisasi. Sedangkan hasil dari penelitian ini diharapkan UMKM dapat memahami penerapan dan pengaplikasian serta menambah pengetahuan mengenai peraturan tarif UMKM terbaru serta dapat memberikan masukkan kepada instansi maupun UMKM dalam menilai 
kebijakan tarif pajak terbaru yaitu PP Nomor 23 Tahun 2018 tentang pajak penghasilan serta mengurangi jumlah pelanggaran terhadap kewajiban pajak.

\section{Metode}

Penelitian ini merupakan penelitian deskriptif yang mendeskripsikan bagaimana persepsi Wajib Pajak Pelaku UMKM terhadap penerapan PP Nomor 23 Tahun 2018. Sumber data dalam penelitian ini adalah data primer yang akan diperoleh secara langsung dari subjek penelitian.

Teknik pengambilan sampel yang digunakan pada penelitian ini menggunakan metode convinience sampling, suatu teknik dalam memilih sampel dengan mempertimbangkan kemudahan akses yang dapat di jangkau berdasarkan kemudahan mendapatkan data (Sakaran, 2006). Sampel pada penelitian ini adalah pelaku UMKM yang telah terdaftar sebagai wajib pajak di KPP Pratama Salatiga.

\section{Teknik Pengumpulan data}

Metode pengumpulan data yang digunakan pada penelitian ini adalah dengan membagikan kuesioner. Kuesioner pada penelitian ini terkait beberapa bagian, diantaranya bagian pertama berisi pertanyaan mengenai biodata responden yang ditujukan untuk memperoleh informasi mengenai profil responden. Bagian kedua berisi tentang sejumlah pertanyaan untuk memperoleh informasi terkait dengan tarif pajak, sanksi pajak, kemudahan pajak, dan sosialisasi atas PP Nomor 23 Tahun 2018, yang nantinya dapat menunjukkan persepsi wajib pajak terhadap penerapan PP Nomor 23 tahun 2018.

Data diperoleh secara langsung dari responden yang terdaftar sebagai wajib pajak pelaku UMKM di KPP Pratama Salatiga. Selanjutnya jawaban responden akan diukur menggunakan skala likert, dengan 5 tingkat jawaban yaitu 1= Sangat Tidak Setuju (STS), 2 = Tidak Setuju (TS), 3 = Ragu-ragu (RR), 4 = Setuju (S) dan 5 = Sangat Setuju (SS). Adapun indikator-indikator di dalam penelitian ini seperti pada tabel 1 dibawah ini:

Tabel 1. Variabel, Definisi Operasional, dan Indikator Empiris Penelitian

\begin{tabular}{|c|c|c|}
\hline Variabel & Definisi Operasional & Indikator \\
\hline \multirow[t]{4}{*}{ Tarif Pajak } & \multirow{4}{*}{$\begin{array}{l}\text { Tarif pajak merupakan suatu } \\
\text { ketentuan dalam bentuk } \\
\text { presentase atau jumlah mata } \\
\text { uang suatu negara yang harus } \\
\text { dibayarkan oleh wajib pajak } \\
\text { berdasarkan pajaknya. } \\
\text { (Permatasari \& Laksito, } \\
\text { 2013). }\end{array}$} & $\begin{array}{l}\text { Wajar apabila kemampuan dalam } \\
\text { membayar pajak penghasilan lebih } \\
\text { besar dikenakan kepada yang } \\
\text { memiliki penghasilan tinggi } \\
\text { dibandingkan dengan yang memiliki } \\
\text { penghasilan yang lebih rendah }\end{array}$ \\
\hline & & $\begin{array}{l}\text { Wajar apabila secara proporsional } \\
\text { yang memiliki penghasilan tinggi } \\
\text { dikenakan pajak dibandingkan } \\
\text { dengan yang memiliki penghasilan } \\
\text { rendah }\end{array}$ \\
\hline & & $\begin{array}{l}\text { Tarif pajak yang adil berarti harus } \\
\text { sama untuk setiap wajib pajak }\end{array}$ \\
\hline & & $\begin{array}{l}\text { Tarif pajak yang dikenakan oleh } \\
\text { wajib pajak akan disesuaikan dengan } \\
\text { penghasilan yang diterima. } \\
\text { (Permatasari \& Laksito, 2013) }\end{array}$ \\
\hline \multirow[t]{4}{*}{ Sanksi pajak } & \multirow{4}{*}{$\begin{array}{l}\text { Sanksi perpajakan merupakan } \\
\text { alat pencegahan agar wajib } \\
\text { pajak tidak melanggar norma } \\
\text { perpajakan (Mardiasmo, } \\
\text { 2009) }\end{array}$} & $\begin{array}{l}\text { Sanksi di kenakan jika terjadi } \\
\text { keterlambatan pembayaran }\end{array}$ \\
\hline & & $\begin{array}{l}\text { Sanksi yang diberlakukan bagi } \\
\text { pelanggar administrasi sangat ringan }\end{array}$ \\
\hline & & $\begin{array}{l}\text { Pengenaan sanksi diberlakukan } \\
\text { untuk menciptakan kepatuhan }\end{array}$ \\
\hline & & $\begin{array}{l}\text { Pengenaan sanksi 2\% dikenakan atas } \\
\text { kurang bayar SPT }\end{array}$ \\
\hline Kemudahan pajak & $\begin{array}{l}\text { Kemudahan pajak dapat } \\
\text { dicapai melalui kemudahan } \\
\text { dalam sistem pajak, undang- }\end{array}$ & $\begin{array}{l}\text { Saya menganggap PP } 23 \text { Tahun } 2018 \\
\text { merupakan peraturan yang lebih } \\
\text { mudah dimengerti dari peraturan }\end{array}$ \\
\hline
\end{tabular}


undang pajak, dan penetapan yang sebelumnya

aturan-aturan perpajakannya. $\quad$ Penetapan tarif tunggal $0,5 \%$

BG Consulting (2003) mempermudah saya menghitung

pajak penghasilan dibandingkan dengan tarif yang berbeda dengan memperhatikan besarnya omzet

Saya menganggap tarif $0,5 \%$ adalah ringan karena pajak yang dibayarkan berkurang

Sosialisasi Sosialisasi merupakan suatu Penyuluhan mengenai PP 23 Tahun

cara belajar mengenai nilai, 2018

aturan, dan tingkah laku yang Diskusi dengan wajib pajak dan

dimaksudkan buat suatu tokoh masyarakat mengenai PP 23

organisasi yang lebih baik Tahun 2018

(Basalamah, 2004).

Informasi langsung dari petugas ke wajib pajak mengenai PP 23 Tahun 2018

Adanya pemasangan billboard Website Ditjen Pajak

\section{Teknik Analisis Data}

Dalam penelitian ini teknik analisis data melalui beberapa tahap, antara lain:

a. Uji validitas

Uji ini mengukur valid atau tidaknya suatu kuesioner (Ghozali, 2011). Suatu kuesioner dikatakan valid apabila pertanyaan di dalam kuesioner mampu untuk mengungkapkan sesuatu yang mampu diukur oleh kuesioner tersebut. Jika $r$ hitung lebih besar dari $r$ tabel dan nilai positif maka dapat dikatakan valid.

b. Uji reliabilitas

Uji reliabilitas bertujuan untuk mengukur suatu kuesioner yang menjadi indikator dari variabel (Ghozali, 2011). Suatu kuesioner dikatakan reliabel atau handal jika jawaban seseorang terhadap pertanyaan adalah konsisten atau stabil dari waktu ke waktu. Formula statistika yang digunakan untuk mengukur reliabilitas adalah uji statistik Cronbach Alpha $(\alpha)$. Apabila nilai Cronbach Alpha $(\alpha)$ dari suatu variabel lebih besar dari 0,5 maka dikatakan variabel tersebut reliabel.

c. Analisis Data Deskriptif

Statistik deskriptif merupakan kegiatan statistik yang dimulai dari menghimpun data, menyusun atau mengatur data, mengolah data, menyajikan dan menganalisis data angka guna memberikan gambaran tentang suatu gejala, peristiwa, atau keadaan (Hartono, 2004). Penelitian ini dianalisis dengan menggunakan uji frekuensi. Frekuensi dari suatu distribusi data penelitian dinyatakan dengan ukuran absolut (f) atau proporsi (\%) dan dapat menggunakan tabel numerik atau grafik (Indrianto dan Supono 2002:171).

\section{Hasil dan pembahasan}

\section{Deskripsi Responden}

Berdasarkan data yang diperoleh dari penyebaran kuesioner yang telah diberikan kepada 100 responden. Hal tersebut dibuktikan dengan kuesioner yang telah dibagikan seluruh pertanyaan dapat terjawab. Selain itu karakteristik responden terhadap jawaban dapat dilihat pada Tabel 2.

Tabel 2. Karakteristik Responden

\begin{tabular}{clcc}
\hline & Karakteristik & Jumlah Responden & Persentase (\%) \\
\hline \multirow{2}{*}{ Jenis Kelamin } & Laki - Laki & 58 & 58 \\
\cline { 2 - 4 } & Perempuan & 42 & 42 \\
\hline \multirow{2}{*}{ Usia } & 20 tahun - 30 tahun & 4 & 4 \\
\cline { 2 - 4 } & 31 tahun - 40 tahun & 39 & 39 \\
\cline { 2 - 4 } & 41 tahun - 50 tahun & 42 & 42 \\
\cline { 2 - 4 } & $>50$ tahun & 15 & 15 \\
\hline
\end{tabular}




\begin{tabular}{|c|c|c|c|}
\hline \multirow{7}{*}{ Pendidikan Terakhir } & SD & 17 & 17 \\
\hline & SMP & 25 & 25 \\
\hline & SMK atau SMA & 37 & 37 \\
\hline & Diploma & 8 & 8 \\
\hline & S1 & 10 & 10 \\
\hline & S2 & 2 & 2 \\
\hline & S3 & 1 & 1 \\
\hline \multirow{3}{*}{ Jenis Usaha } & Dagang & 51 & 51 \\
\hline & Jasa & 16 & 16 \\
\hline & Industri & 33 & 33 \\
\hline \multirow{3}{*}{ Omset Per Tahun } & $\leq \mathrm{Rp} 300.000 .000,00$ & 86 & 86 \\
\hline & $\begin{array}{l}\mathrm{Rp} 300.000 .000,00 \\
\mathrm{Rp} 2.500 .000 .000,00\end{array}$ & 12 & 12 \\
\hline & $\begin{array}{l}\text { Rp 2.500.000.000,00- } \\
\text { Rp 4.800.000.000,00 }\end{array}$ & 2 & 2 \\
\hline
\end{tabular}

Sumber: Data primer diolah (2019)

Berdasarkan Tabel di atas, karakteristik responden dapat dilihat dari jenis kelamin bahwa mayoritas responden berjenis kelamin laki- laki dengan persentase 58 persen, sisanya sebanyak 42 persen berjenis kelamin perempuan. Karakteristik responden berdasarkan usia mayoritas responden memiliki rentang usia 41 tahun sampai 50 tahun dengan 42 persen. Pada rentang usia 20 tahun sampai 30 tahun memiliki persentase sebesar 4 persen, rentang usia 31 tahun sampai 40 tahun memiliki persentase sebesar 39 persen, sedangkan rentang usia di atas 50 tahun memiliki persentase sebesar 15 persen.

Karakteristik responden berdasarkan pendidikan terakhir, mayoritas yang berpendidikan terakhir SMK atau SMA yaitu sebesar 37 persen. Responden yang berpendidikan terakhir SD, SMP, Diploma, S1 dan S2 berturut - turut memiliki persentase sebesar 17, 25, 8, 10, dan 2 persen. Sedangkan responden yang berpendidikan terakhir S3 memiliki persentase sebesar 1 persen.

Berdasarkan jenis usaha sebesar 51 persen responden merupakan jenis usaha dagang. Responden yang berjenis usaha jasa dan industri memiliki persentase sebesar 16 persen dan 33 persen. Berdasarkan omset per tahun, responden yang memiliki omset di bawah Rp 300.000.000 memiliki persentase sebesar 86 persen. Omset per tahun antara Rp 300.000.000 sampai Rp 2.500.000.000 memiliki persentase sebesar 12 persen, sedangkan $\mathrm{Rp} 2.500 .000 .000$ sampai $\mathrm{Rp} 4.800 .000 .000$ memiliki persentase sebesar 2 persen.

\section{Uji Validitas}

Uji validitas dilakukan untuk mengukur ketepatan suatu item pernyataan dengan membandingkan tabel $\mathrm{r}$ dengan kolom Corrected Item-Total Correlation. Apabila Corrected Item Total menunjukkan lebih dari $r$ tabel yang ditentukan yaitu 0,1966 maka data dapat dikatakan valid. Hasil pengujian validitas pada penelitian ini dapat dilihat pada Tabel 3.

Tabel 3. Hasil Uji Validitas

\begin{tabular}{|c|c|c|c|c|}
\hline & & Corrected Item-Total Correlation & $\mathbf{r}$ tabel & Keterangan \\
\hline \multirow{4}{*}{ Tarif Pajak } & A1 & 0,793 & 0,1966 & Valid \\
\hline & A2 & 0,812 & 0,1966 & Valid \\
\hline & A3 & 0,599 & 0,1966 & Valid \\
\hline & A4 & 0,716 & 0,1966 & Valid \\
\hline \multirow{4}{*}{ Sanksi Pajak } & B1 & 0,732 & 0,1966 & Valid \\
\hline & B2 & 0,789 & 0,1966 & Valid \\
\hline & B3 & 0,598 & 0,1966 & Valid \\
\hline & B4 & 0,732 & 0,1966 & Valid \\
\hline \multirow{3}{*}{$\begin{array}{c}\text { Kemudahan } \\
\text { Pajak }\end{array}$} & C1 & 0,863 & 0,1966 & Valid \\
\hline & $\mathrm{C} 2$ & 0,905 & 0,1966 & Valid \\
\hline & $\mathrm{C} 3$ & 0,852 & 0,1966 & Valid \\
\hline \multirow{2}{*}{$\begin{array}{l}\text { Sosialisasi } \\
\text { Pajak }\end{array}$} & D1 & 0,609 & 0,1966 & Valid \\
\hline & D2 & 0,632 & 0,1966 & Valid \\
\hline
\end{tabular}




\begin{tabular}{lllll}
\hline D3 & 0,615 & 0,1966 & Valid \\
\cline { 2 - 5 } D4 & 0,561 & 0,1966 & Valid \\
\cline { 2 - 5 } D5 & 0,565 & 0,1966 & Valid \\
\cline { 2 - 5 } & D6 & 0,532 & 0,1966 & Valid \\
\hline
\end{tabular}

(Sumber data : Diolah SPSS, 2019)

Berdasarkan uji validitas didapatkan Corrected Item-Total Correlation semua item pernyataan pada penelitian ini menunjukkan hasil di atas $r$ hitung yaitu sebesar 0,1966. 4 item pernyataan pada variabel tarif pajak, 4 item pernyataan pada variabel sanksi pajak, 3 item pernyataan pada variabel kemudahan pajak dan 6 item pernyataan pada variabel sosialisasi pajak dapat dikatakan valid karena sudah memenuhi dengan kualifikasi yang ditentukan.

\section{Uji Reliabilitas}

Uji reliabilitas dilakukan untuk menguji keandalan dari suatu instrumen yang diukur. Data yang diolah dikatakan reliabel jika Cronbach's Alpha lebih besar dibandingkan dengan nilai kritis yaitu sebesar 0,60. Hasil pengujian reliabilitas pada penelitian ini dapat dilihat pada Tabel 4.

Tabel 3. Hasil Uji Reliabilitas

\begin{tabular}{lccc}
\hline \multicolumn{1}{c}{ Variabel } & Cronbach's Alpha & Nilai Kritis & Keterangan \\
\hline Tarif Pajak & 0,711 & 0,60 & Reliabel \\
Sanksi Pajak & 0,679 & 0,60 & Reliabel \\
Kemudahan Pajak & 0,833 & 0,60 & Reliabel \\
Sosialisasi Pajak & 0,616 & 0,60 & Reliabel \\
\hline
\end{tabular}

(Sumber data : Diolah SPSS, 2019)

Berdasarkan Tabel di atas menunjukkan bahwa data yang telah diolah yaitu reliabel. Hal tersebut dapat ditunjukkan dengan melihat Cronbach's Alpha lebih dari standar atau nilai kritis sebesar 0,60. Dapat diartikan bahwa seluruh item pertanyaan yang mencakup mengenai variabel tarif, sanksi, kemudahan serta sosialisasi sudah reliabel jika dihadapkan dengan pernyataan mengenai persepsi pelaku wajib pajak UMKM.

\section{Persepsi Wajib Pajak Pelaku UMKM terhadap Tarif Pajak PP 23 Tahun 2018}

Dari variabel yang telah ditentukan yaitu tarif pajak PP 23 Tahun 2018 telah mendapatkan respon yang baik terhadap tarif yang ditentukan sebesar 0,5 persen bagi wajib pajak pelaku UMKM. Hal tersebut dapat dilihat pada Tabel 4 berikut ini :

Tabel 4. Distribusi Frekuensi dan Persentase Tarif Pajak PP 23 Tahun 2018

\begin{tabular}{|c|c|c|c|c|c|c|}
\hline \multirow{2}{*}{ No } & \multirow{2}{*}{ Pertanyaan } & \multicolumn{5}{|c|}{ Persentase Jawaban (\%) } \\
\hline & & STS & TS & $\mathbf{R R}$ & $\mathbf{S}$ & SS \\
\hline 1. & $\begin{array}{l}\text { Apakah anda setuju dengan penerapan } \\
\text { tarif pajak final sebesar } 0,5 \% \text { dari nilai } \\
\text { peredaran bruto }\end{array}$ & 3 & 7 & 24 & 56 & 10 \\
\hline 2. & $\begin{array}{l}\text { Apakah dengan pengenaan tarif pajak } \\
0,5 \% \text { ini tidak memberatkan bagi UMKM }\end{array}$ & 3 & 12 & 30 & 45 & 10 \\
\hline 3. & $\begin{array}{l}\text { Apakah anda setuju penerapan PP } 23 \\
\text { Tahun } 2018 \text { dengan tarif } 0.5 \% \text { dari nilai } \\
\text { bruto dapat mengurangi beban } \\
\text { administrasi dalam pembayaran pajak } \\
\text { UMKM }\end{array}$ & 2 & 4 & 15 & 59 & 20 \\
\hline 4. & $\begin{array}{l}\text { Apakah anda paham mekanisme } \\
\text { perhitungan tarif final 0,5\% dari Omzet } \\
\text { usaha }\end{array}$ & 1 & 14 & 17 & 52 & 16 \\
\hline & Rata- rata & 2,25 & 9,25 & 21,5 & 53 & 14 \\
\hline
\end{tabular}

(Sumber data : Diolah SPSS, 2019) 
Berdasarkan distribusi frekuensi dan persentase pada tabel 4 menunjukkan bahwa persepsi wajib pajak terhadap penetapan tarif pajak sebesar 0,5 persen mendapat respon yang cukup baik karena banyak ditemukan jawaban setuju hingga sangat setuju terkait penetapan tarifnya. Responden merasa besarnya tarif pajak yang dibayarkan sudah wajar dibandingkan dengan tarif pajak sebelumnya yaitu dengan rata- rata tertinggi sebanyak 53 persen menjawab setuju dan respon terendah yaitu rata- rata sebanyak 2,25 persen menjawab sangat tidak setuju. Hal ini dapat dilihat dari 56 persen responden menjawab setuju dengan penetapan tarif sebesar 0,5 persen, dikarenakan jumlah pajak yang harus dibayarkan disesuaikan dengan nilai peredaran bruto.

Sedangkan sebanyak 45 persen responden menganggap bahwa besaran pajak yang dibayarkan tidak memberatkan. Selain itu wajib pajak juga merasakan bahwa penetapan PP 23 Tahun 2018 dapat mengurangi beban administrasi dalam pembayaran pajak, serta sebanyak 52 persen responden memahami bagaimana mekanisme perhitungan tarif final 0,5 persen omset usaha.

\section{Persepsi Wajib Pajak Pelaku UMKM terhadap Sanksi Pajak PP 23 Tahun 2018}

Dari variabel yang telah ditentukan yaitu sanksi pajak PP 23 Tahun 2018 telah mendapatkan respon yang baik. Hal tersebut dapat dilihat pada Tabel 5 berikut ini :

Tabel 5. Distribusi Frekuensi dan Persentase Sanksi Pajak PP 23 Tahun 2018

\begin{tabular}{|c|c|c|c|c|c|c|}
\hline \multirow{2}{*}{ No } & \multirow{2}{*}{ Pertanyaan } & \multicolumn{5}{|c|}{ Persentase Jawaban (\%) } \\
\hline & & STS & TS & $\mathbf{R R}$ & $\mathbf{S}$ & SS \\
\hline 1. & $\begin{array}{l}\text { Sanksi denda bagi UMKM diberlakukan jika terjadi } \\
\text { keterlambatan pembayaran atas PP No.23 tahun } \\
2018\end{array}$ & 7 & 5 & 33 & 32 & 23 \\
\hline 2. & $\begin{array}{l}\text { Sanksi keterlambatan pembayaran atas PP No.23 } \\
\text { tahun } 2018 \text { tidak memberatkan bagi UMKM }\end{array}$ & 6 & 16 & 36 & 31 & 11 \\
\hline 3. & $\begin{array}{l}\text { Sanksi keterlambatan pembayaran atas PP No. } 23 \\
\text { tahun } 2018 \text { diberlakukan untuk menciptakan } \\
\text { kepatuhan bagi UMKM dalam melaksanakan } \\
\text { kewajiban perpajakan. }\end{array}$ & 1 & 7 & 24 & 64 & 4 \\
\hline 4. & $\begin{array}{l}\text { Sanksi dikenakan } 2 \% \text { atas kurang bayar SPT tidak } \\
\text { memberatkan bagi UMKM }\end{array}$ & 15 & 32 & 24 & 27 & 2 \\
\hline & Rata- rata & 7,25 & 15 & 29,25 & 38,5 & 10 \\
\hline
\end{tabular}

Berdasarkan distribusi frekuensi dan persentase pada tabel 5 Responden menganggap bahwa sanksi pajak diberlakukan tidak memberatkan dan merasa bahwa dengan adanya sanksi atas keterlambatan pembayaran pajak dapat menciptakan kepatuhan wajib pajak dalam melaksanakan kewajiban perpajakannya. Hal ini dilihat dari rata- rata tertinggi sebanyak 38,5 persen yang menyatakan setuju dan rata- rata terendah sebanyak 7,25 persen responden yang menyatakan sangat tidak setuju.

Namun, masih banyak juga yang masih merasa ragu akan adanya sanksi pajak, Hal ini dapat dilihat dari rata- rata sebanyak 29 persen responden menjawab ragu - ragu dan sebanyak 33 persen responden menjawab ragu- ragu dengan adanya pemberlakuan sanksi apabila terjadi keterlambatan pembayaran, dikarenakan masih kurangnya pengetahuan akan pentingnya membayar pajak.

\section{Persepsi Wajib Pajak Pelaku UMKM terhadap Kemudahan Pajak PP 23 Tahun 2018}

Dari variabel yang telah ditentukan yaitu kemudahan pajak PP 23 Tahun 2018 telah mendapatkan respon yang baik. Hal tersebut dapat dilihat pada tabel 6 berikut ini :

Tabel 6. Distribusi Frekuensi dan Persentase Kemudahan Pajak PP 23 Tahun 2018

\begin{tabular}{|c|c|c|c|c|c|c|}
\hline \multirow{2}{*}{ No } & \multirow{2}{*}{ Pertanyaan } & \multicolumn{5}{|c|}{ Persentase Jawaban (\%) } \\
\hline & & STS & TS & $\mathbf{R R}$ & $\mathbf{S}$ & SS \\
\hline 1. & $\begin{array}{l}\text { PP No.23 tahun } 2018 \text { merupakan peraturan yang } \\
\text { lebih mudah dimengerti dari peraturan yang } \\
\text { sebelumnya }\end{array}$ & 0 & 3 & 21 & 46 & 30 \\
\hline 2. & Penetapan tarif tunggal $0,5 \%$ mempermudah & 0 & 4 & 16 & 54 & 26 \\
\hline
\end{tabular}




\begin{tabular}{|c|c|c|c|c|c|c|}
\hline & $\begin{array}{l}\text { dalam menghitung pajak penghasilan } \\
\text { dibandingkan dengan tarif yang berbeda dengan } \\
\text { memperhatikan besarnya omzet }\end{array}$ & & & & & \\
\hline 3. & $\begin{array}{l}\text { Tarif } 0,5 \% \text { adalah ringan karena pajak yang } \\
\text { dibayarkan berkurang }\end{array}$ & 0 & 9 & 24 & 31 & 36 \\
\hline & Rata- rata & 0 & 5,3 & 20,3 & 43,6 & 30,6 \\
\hline
\end{tabular}

Berdasarkan distribusi frekuensi dan persentase pada tabel 6 menunjukkan bahwa persepsi wajib pajak terhadap kemudahan pajak PP 23 tahun 2018 menunjukkan respon yang cukup baik, sebagian besar responden sudah tidak merasa kesulitan dengan proses pembayaran dan perhitungan pajak saat ini. Hal ini dilihat dari rata- rata tertinggi sebanyak 43,6 persen responden menjawab setuju dan dengan ratarata terendah sebanyak 5,3 persen menjawab tidak setuju.

Namun masih ditemukan beberapa responden masih merasa ragu dengan kemudahan pajak yang ditawarkan. Dilihat dari rata- rata sebanyak 20,3 persen responden menjawab ragu-ragu, dikarenakan responden merasa bahwa perhitungan pajak di masa mendatang akan lebih sulit karena harus membuat pembukuan. Sedangkan sebagian besar responden tidak paham mengenai pembukuan dan tidak mau membuat pembukuan yang dianggap rumit.

\section{Persepsi Wajib Pajak Pelaku UMKM terhadap Sosialisasi pajak PP 23 Tahun 2018}

Dari variabel yang telah ditentukan yaitu sosialisasi pajak PP 23 Tahun 2018 telah mendapatkan respon yang cukup baik. Hal tersebut dapat dilihat pada Tabel 7 berikut ini :

Tabel 7. Distribusi Frekuensi dan Presentase Sosialisasi Pajak PP 23 Tahun 2018

\begin{tabular}{|c|c|c|c|c|c|c|}
\hline \multirow{2}{*}{ No } & \multirow{2}{*}{ Pertanyaan } & \multicolumn{5}{|c|}{ Persentase Jawaban (\%) } \\
\hline & & STS & TS & RR & $\mathbf{S}$ & SS \\
\hline 1. & $\begin{array}{l}\text { Petugas KPP (Kantor Pelayanan Pajak) selalu } \\
\text { melakukan penyuluhan mengenai PP No.23 tahun } \\
2018 \text { tentang Pajak Penghasilan UMKM }\end{array}$ & 3 & 11 & 36 & 27 & 23 \\
\hline 2. & $\begin{array}{l}\text { Petugas KPP (Kantor Pelayanan Pajak) sering } \\
\text { mengajak diskusi wajib pajak mengenai PP No.23 } \\
\text { tahun } 2018 \text { tentang Pajak Penghasilan UMKM }\end{array}$ & 1 & 29 & 21 & 22 & 27 \\
\hline 3. & $\begin{array}{l}\text { Petugas KPP (Kantor Pelayanan Pajak) sering } \\
\text { memberi informasi mengenai PP No.23 tahun } 2018 \\
\text { tentang Pajak Penghasilan UMKM }\end{array}$ & 1 & 9 & 34 & 31 & 25 \\
\hline 4. & $\begin{array}{l}\text { Sosialisasi mengenai PP No.23 tahun } 2018 \text { melalui } \\
\text { Website Ditjen pajak sangat lengkap }\end{array}$ & 2 & 10 & 39 & 37 & 12 \\
\hline 5. & $\begin{array}{l}\text { Sosialisasi mengenai PP No.23 tahun } 2018 \\
\text { menggunakan billboard atau reklame lebih efektif } \\
\text { dibandingkan melalui website } \\
\text { Ditjen Pajak }\end{array}$ & 0 & 2 & 40 & 27 & 31 \\
\hline 6. & $\begin{array}{l}\text { Sosialisasi mengenai PP No.23 tahun } 2018 \text { sudah di } \\
\text { laksanakan dengan baik oleh petugas KPP Pratama } \\
\text { Salatiga }\end{array}$ & 0 & 10 & 20 & 48 & 22 \\
\hline & Rata- rata & 1,16 & 11,8 & 31,6 & 32 & 23,3 \\
\hline
\end{tabular}

(Sumber data : Diolah SPSS, 2019)

Berdasarkan distribusi frekuensi dan persentase pada tabel 7 sebagian besar responden sudah merasa mendapatkan sosialisasi terkait penerapan PP 23 tahun 2018 dan sosialisasi sudah dilaksanakan dengan baik dilihat dari rata- rata tertinggi sebanyak 32,0 persen responden menjawab setuju dan ratarata terendah 1,16 persen menjawab sangat tidak setuju. Namun juga masih ditemukan beberapa responden masih menjawab ragu- ragu dan merasa sosialisasi yang telah dilakukan oleh KPP belum maksimal dapat dilihat dengan rata- rata jawaban sebanyak 31,6 persen. Hal ini juga dapat dilihat bahwa sebanyak 36 persen ragu- ragu dengan adanya penyuluhan petugas KPP terkait PP 23 Tahun 2018. 


\section{Simpulan dan saran}

Berdasarkan hasil dan pembahasan dapat disimpulkan bahwa persepsi Wajib Pajak Pelaku UM KM terhadap PP 23 Tahun 2018 di tinjau dari tarif, sanksi, kemudahan dan sosialisasi pajak secara keseluruhan sudah cukup baik, serta telah memberikan pemahaman dan menawarkan kemudahan dalam pembayaran pajak pelaku UMKM. Meskipun dari data yang telah diperoleh masih ditemukan beberapa responden yang kurang memahami terkait peraturan ini. Perlunya meningkatkan sosialisasi mengenai PP 23 Tahun 2018 kepada wajib pajak khususnya pelaku UMKM agar mengerti dan paham tentang manfaat membayar pajak dan dikenakan sanksi jika tidak membayar pajak.

Berdasarkan penelitian yang telah dibuat, diharapkan penelitian selanjutnya dapat mengembangkan objek penelitian lebih luas. Hal tersebut untuk melihat bagaimana persepsi wajib pajak UMKM secara luas terhadap PP 23 Tahun 2018 yang telah ditetapkan oleh pemerintah.

\section{Daftar Rujukan}

Andriani , Y., \& Herianti, E. (2015). Pengaruh sosialisasi pajak, pemahaman perpajakan, dan tingkat pendidikan terhadap kepatuhan wajib pajak UMKM. Syariah paper accounting FEB UMS, ISSN 24600784 .

Basalamah, A. S. (2004). Perilaku Organisasi Memahami Dan Mengelola Aspek Humaniora Dalam Organisasi (Edisi Tiga ed.). Depok: Usaha Kami.

Consulting, B. (2003). Tax Simplicity and Stability: Attractive to Countries and Investors. United Stated: BG Consulting, Inc.

Ghozali, I. (2011). aplikasi analisis multivariat dengan proram IBM SPSS. Semarang: Diponegoro University press.

Ghozali, I. (2011). Aplikasi Analisis Multivariate dengan Program IBM SPSS 19. Semarang: Badan Penerbit Universitas Diponegoro.

Holtzman, Y. (2007). Challenges in achieving transparency, simplicity and administering of the united stated tax code. Journal of management development, XXVI No.5, 418-427.

Kurniawati, M., \& Toly, A. A. (2014). Analisis Keadilan Pajak, Biaya Kepatuhan dan Tarif Pajak Terhadap Persepsi Wajib Pajak Mengenai Penggelapan Pajak DI Surabaya Barat. Tax \& Accounting Review Vol. 4 No.2, 1-12.

Lubis, A. I. (2010). Akuntansi Keperilakuan (Edisi Kedua ed.). Jakarta: Salemba Empat.

Mardiasmo. (2009). Perpajakan (Edisi Revisi ed.). Yogyakarta: Andi Yogyakarta.

Nayoan, N. (2016, Februari). Pengaruh Pemahaman Wajib Pajak, Kemudahan Membayar Pajak, dan Perubahan Tarif PP No. 46 Tahun 2013 Terhadap Kepatuhan Wajib Pajak UMKM di Kota Pekanbaru. JOM Fekon, Vol.3 No.1, 763-777.

Norsain, \& Abu Yasid. (2014). Pengaruh Perubahan Tarif, Kemudahan Membayar Pajak, dan Sosialisasi PP Nomor 46 Tahun 2013 Terhadap Persepsi Wajib Pajak UMKM. "Performance" Bisnis Akuntansi, Vol. IV, No. 2, 1-13.

Nugroho, A. (2006). Pengaruh Sikap Wajib Pajak pada Pelaksanaan Sanksi Denda, Pelayanan Fiskus dan Kesadaran Perpajakan terhadap Kepatuhan Wajib Pajak (Studi Empiris terhadap Wajib Pajak Orang Pribadi di Kota Semarang). Tesis Magister Akuntansi Program Pascasarjana Universitas Diponegoro. 
Permatasari, I., \& Laksito, H. (2013). Minimalisasi Tax Evasion Melalui Tarif Pajak, Teknologi dan Pengeluaran Pemerintah (Studi Empiris pada Wajib Pajak Orang Pribadi di Wilayah KPP Pratama Pekanbaru Senapelan). Jurnal UNDIP, Vol.2, 1-10.

Rachmawati, N. A., \& Ramayanti, R. (2016). Manfaat Pemberian Insentif Pajak Penghasilan dalam Kepatuhan Wajib Pajak UMKM. Jurnal Akuntansi, Ekonomi dan Manajemen Bisnis, VOL. 4, No. 2, 176185.

Rahayu, S. K. (2010). Perpajakan Indonesia : Konsep Dan Aspek Formal. Yogyakarta: Graha ILmu.

Sakaran, U. (2006). Metodologi Penelitian Untuk Bisnis. Jakarta: Salemba Empat.

Sari, R. (2018, Juni). Kebijakan InseNtif Pajak Bagi Usaha Mikro, Kecil, dan Menengah. Info Singkat, Vol. X, No. 12(Aktual dan Strategis).

Setiawan, F. X. (2018, Juli 11). Penurunan Tarif Pajak UMKM, Antara Keadilan dan Kejujuran Wajib Pajak. Retrieved Oktober 09, 2018, from www.pajak.go.id: http://www.pajak.go.id/article/penurunantarif-pajak-umkm-antara-keadilan-dan-kejujuran-wajib-pajak.

Sudirman, \& Amirudin. (2012). Perpajakan Pendekatan Teori dan Praktik di Indonesia. Jakarta: Salemba Empat Dua Media.

Suhendri, D. (2015). Pengaruh pengetahuan, tarif pajak, dan sanksi pajak terhadap kepatuhan wajib pajak orang pribadi yang melakukan kegiatan usaha dan peerjaan bebas di kota padang.

Supadmi, N. L., \& Suputra, D. D. (2016). Persepsi Wajib Pajak atas Pemberlakuan Peraturan Pemerintah Nomor 46 Tahun 2013 dan Pengaruhnya pada Kepatuhan Perpajakan (Studi Kasus Pada UMKM Di Kota Denpasar). JUrnal Manajemen \& Akuntansi STIE Triatma Mulya, Vol. 22, No. 2, 95-107.

Waluyo. (2011). Perpajakan Indonesia. Jakarta: Salemba Empat.

Wenerungan, O. L. (2013, September). Sosialisasi Perpajakan, Pelayanan Fiskus dan sanksi Perpajakan Terhadap Kepatuhan WPOP Di KPP Manado dan KPP Bitung. Jurnal EMBA, Vol.1 No.3, 960-970.

Yadnyana, I. K. (2009). Pengaruh Moral dan Sikap Wajib Pajak Koperasi di Kota Denpasar. Fakultas Ekonomi Universitas Udayana. Denpasar.

Zain, M. (2008). Manajemen Perpajakan . Jakarta: Salemba Empat. 